\title{
Mechanical Isolation of Human Endothelial Cells from Large Vessels for Flow Cytometry Immunophenotyping
}

\section{Cláudia Torres ${ }^{1,2}$, Rui Machado ${ }^{3,4}$ and Margarida Lima ${ }^{1,2,4 *}$}

${ }^{1}$ Laboratório de Citometria, Serviço de Hematologia Clínica, Hospital de Santo António (HSA), Centro Hospitalar do Porto (CHP), Rua D. Manuel I, 4099-001 Porto, Portugal ${ }^{2}$ Unidade Multidisciplinar de Investigação Biomédica (UMIB), Instituto de Ciências Biomédicas Abel Salazar da Universidade do Porto (ICBAS/UP), Rua de Jorge Viterbo Ferreira $n .{ }^{\circ} 228,4050-313$ Porto, Portugal

${ }^{3}$ Serviço de Angiologia e Cirurgia Vascular, Hospital de Santo António (HSA), Centro Hospitalar do Porto (CHP), Largo Prof. Abel Salazar n. ${ }^{\circ}$, $4099-001$ Porto, Portugal ${ }^{4}$ Instituto de Ciências Biomédicas Abel Salazar da Universidade do Porto (ICBAS/UP), Rua de Jorge Viterbo Ferreira $n .{ }^{\circ} 228,4050-313$ Porto, Portugal

\begin{abstract}
Endothelial cells (EC) have important physiological functions, and they may also have a role in pathology. To better understand their role in health and disease, we must know very well their phenotype. Previous studies have identified and characterized EC mainly by immunohistochemistry, but there are also some studies using flow cytometry (FCM) after exposing these cells to enzymatic digestion, either to isolate and/ or to detach them from the vessel wall. However, it is well known that enzymatic treatment can cause deleterious effects on cell surface receptors, then influencing the antibody-antigen reaction. We describe a simple and cheap mechanical method to isolate EC from human vessels, avoiding alterations in the expression of cell surface receptors caused by the use of enzymes, and we tested it using FCM. With this method we were able to obtain fresh EC that were identified by FCM as a well-defined cluster of CD45-CD146 ${ }^{\text {+bright }}$ CD $31^{\text {tright }}$ cells. This approach can be used in the future to isolate EC for further immunophenotypic characterization and for ex-vivo functional studies, as well as to test the effect of different stimuli, including pharmacological drugs.
\end{abstract}

Keywords: Endothelial cells; Human veins; Mechanical isolation; Flow cytometry; Immunophenotyping

Abbreviations: APC: Allophycocyanin; BSA: Bovine Serum Albumin; CV: Coefficient of Variation; EC: Endothelial Cells; FCM: Flow Cytometry; FITC: Fluorescein Isothiocyanate; FSC: Forward Side Scatter; HSVEC: Human Saphenous Veins Endothelial Cells; mAb: Monoclonal Antibody; MFI: Mean Fluorescence Intensity; PBS: Phosphate Buffer Saline; Percp: Peridinin-Chlorophyll Protein; PerCPCy 5.5: Peridinin-Chlorophyll Protein Complex With Cyanin 5.5; PE: Phycoerythrin; SSC: Side Scatter; V450: Violet 450

\section{Introduction}

Endothelial cells (EC) have multiple functions, including transport of nutrients and solutes, maintenance of the vascular tone, resistance to thrombosis, activation and inactivation of vasoactive hormones, angiogenesis, and innate and adaptive immunity [1-4]. It is also recognized that they are involved in several diseases, either as primary physiopathology determinants or as victims of collateral damage [5]. Nonetheless, there are many questions to answer concerning the EC characteristics, as well as their potential contribution to various disease states. Difficulties in characterizing the EC appear mainly because they are difficult to obtain due to their localization, as they are disposed as a monolayer covering the inner surface of the vessel walls. Thus, most of the actual knowledge about the EC was obtained by histology and immunohistochemistry studies on segments of veins or performing cultures of EC extracted from the blood vessels using enzymatic methods [6-13]. It is well known that both techniques are time consuming and have disadvantages, sometimes masking cell receptor expression. Even though immunohistochemistry gives morphological interpretation, it does not allow the quantification and analysis of multiple phenotypic markers as flow cytometry (FCM) does [14]. Moreover, immunohistochemistry has various factors that influence the quality of the staining, contributing to the presence of false positive or false negative results. This occurs mainly because of tissue fixation, which can change the chemical properties of cell constituents and alter the three-dimensional protein conformation by cross-linking, interfering with epitope accessibility and/or generating non-specific staining [15-18]. In what regards to the method of isolation, several authors have reported the injurious effects of the enzymes in cell surface proteins and other cell structures, thereby modifying cell phenotype [9,14,19-25]. In view of these observations, mechanical cell isolation has the advantage of preserving cell surface receptors.

Flow cytometry is a fast and versatile technique that allows the detailed phenotypic characterization of the cells, allowing the study of cell maturation, activation and apoptosis related markers in simultaneously, as well as functional studies [26]. The identification and characterization of EC by FCM must be carried out carefully, concerning not only the method used to isolate the EC, but also the monoclonal antibodies (mAbs) used, since until now there are not EC specific markers. In our experience, among the several molecules expressed, the CD45, CD146 and CD31 offer one of the best combinations to guaranty a proper identification of the EC [27]. The Leukocyte Common Antigen (LCA, CD45) is present on most leukocytes, whereas it is not expressed on the EC. The Platelet Endothelial Cell Adhesion Molecule-1 (PECAM-1, or EndoCAM, CD31) is a 130-140 KD type I transmembrane glycoprotein that acts as an adhesion molecule involved in homotypic or heterotypic cell-to-cell interactions and trans-endothelial migration of leukocytes;

*Corresponding author: Margarida Lima, Laboratório de Citometria, Serviço de Hematologia Clínica, Hospital de Santo António (HSA), Centro Hospitalar do Porto (CHP), Rua D. Manuel I, 4099-001 Porto, Portugal, Tel: +351966327115, E-mail: mmc.lima@clix.pt

Received January 12, 2016; Accepted January 28, 2016; Published February 05, 2016

Citation: Torres C, Machado R, Lima M (2016) Mechanical Isolation of Human Endothelial Cells from Large Vessels for Flow Cytometry Immunophenotyping. J Tissue Sci Eng 7: 163. doi:10.4172/2157-7552.1000163

Copyright: @ 2016 Torres C, et al. This is an open-access article distributed under the terms of the Creative Commons Attribution License, which permits unrestricted use, distribution, and reproduction in any medium, provided the original author and source are credited. 
it is expressed in EC, granulocytes, monocytes, lymphocyte subsets and platelets $[28,29]$. Melanoma Cell Adhesion Molecule (MCAM or Mel-CAM, CD146), is also a cell adhesion molecule that is primarily expressed at the intercellular junctions of the EC, vascular pericytes and smooth muscle cells, although being also present on activated memory T-cells, as well as on a small fraction of B- and NK-cells; recent evidence indicates that CD146 is involved in various biological processes, including mesenchymal stem cell differentiation, signaling transduction, cell migration, angiogenesis and immune response, and acts as a co-receptor for Vascular Endothelial Growth Factor Receptor type 2 (VEGFR-2, CD309) [30-33].

In this paper, we describe an easy and cheap mechanical method to isolate EC from human vessels. This method was used to isolate human saphenous vein endothelial cells (HSVEC) in order to identify and characterize them by FCM, using anti-CD45, anti-CD146 and anti-CD31 mAbs and a wash-stain-lyse-no-fix-no-wash procedure. With this staining, we assure the exclusion of other cells that often contaminate the EC suspension and may induce false positive results, such as leukocytes and perivascular cells [34-39]. Although nonenzymatic methods have been used for more than 3 decades to isolate EC $[9,12,40-42]$, to the best of our knowledge multi-parametric FCM was never used to characterize the immunophenotype of mechanically isolated fresh EC.

\section{Material and Methods}

\section{Study approval}

The study was approved by the hospital ethics committee and administration board. All patients were informed and gave their written consent.

\section{Vascular samples}

The segments of human saphenous veins were obtained from 10 patients undergoing surgery for varicose veins, recruited at the Department of Angiology and Vascular Surgery, Hospital de Santo António, Centro Hospitalar do Porto, Porto, Portugal. A vein segment with 1.5 to $4.0 \mathrm{~cm}$ of length was removed from each patient during surgery, put into a recipient with saline solution $(0.9 \% \mathrm{NaCl})$ and transported to the laboratory within 1 to 3 hours.

\section{Cell disaggregation}

As soon as the vein segments arrived to the laboratory, they were immediately transferred into a recipient with phosphate buffered saline (PBS, pH 7.2) containing 2\% (weight/volume) bovine serum albumin (BSA) (PBS-2\%BSA). After 15 minutes, the vein segment was placed inside a Petri disk over a styrofoam square covered with laboratory film (Parafilm ${ }^{\circ}$, Bemis Flexible Packaging, Neenah, Wisconsin, USA), to ensure the presence of a hydrophobic surface, in order to avoid PBS-2\%BSA to spread from the vein surface. One of the extremities of the vein segment was fixed to the styrofoam with needles, and the vein segment was covered with a few drops of PBS-2\%BSA with the help of a Pasteur pipette to prevent cell dehydration. After removing the connective tissue of the vessel wall with the help of a scissor and a forceps, a longitudinal cut was made along the vein segment with the scissor, and the vascular surface lumen was exposed upwards. The open vein was then fixed with needles to the styrofoam and more drops of PBS-2\%BSA were added to the luminal surface. Afterwards, the EC were mechanically removed from the vessel wall by gently squeezing in continuous movement, with two serrated forceps, without perforating the vascular surface. Next, the cells were suspended in PBS-2\%BSA, aspirated with a Pasteur pipette and transferred into a $15 \mathrm{ml}$ conical polypropylene tube. The vessel lumen was immediately covered with more drops of PBS-2\%BSA and the process was repeated several times to recover the maximum of EC. The cell suspension was left to rest 5 to 15 minutes inside the tube, in order to allow the gravitational deposit of tissue fragments and clumps, then transferred into another $15 \mathrm{ml}$ conical polypropylene tube and centrifuged at $300 \mathrm{xg}$ for 5 minutes at room temperature. After centrifugation, the supernatant was removed and $2 \mathrm{ml}$ of PBS-2\%BSA were added to the pellet, where cells were gently suspended by several up and down movements with a Pasteur pipette, until cell aggregates disappear. Finally, the cell suspension was transferred into a $12 \times 75$ polypropylene tube and washed once again ( $300 \times \mathrm{g}$ for 5 minutes). After removing the supernatant and adding 500 $\mu \mathrm{L}$ of PBS-2\%BSA, the cells were used for immunophenotyping.

\section{Cell immunophenotyping}

Cell immunophenotyping was performed using direct immunofluorescence staining and a lyse-no-fix-no-wash method. Briefly, $100 \mu \mathrm{l}$ of cell suspension containing 0.5 to $1 \times 10^{6}$ cells were transferred into a polystyrene FACS ${ }^{\oplus}$ tube $12 \times 75$ (Becton Dickinson Biosciences, BDB, catalog no. 352052) and incubated for 15 minutes at the room temperature, with the appropriate volume of anti-CD146 (Melanoma Cell Adhesion Molecule, MCAM) (clone P1H12, BD Pharmingen), anti-CD45 (Leukocyte Common Antigen, LCA) (clone 2D1, BDB) and anti-CD31 (Platelet endothelial cell adhesion molecule, PECAM) (clone WM59, BDB) mouse anti-human mAbs conjugated with phycoerythrin (PE), peridinin-chlorophyll protein (PerCP) and violet 450 (V450), respectively. Unstained cells were used as controls. Once finished the incubation period, the erythrocytes were destroyed by adding $500 \mu \mathrm{L}$ of Quicklysis ${ }^{\mathrm{m}}$ solution (Cytognos, Salamanca, Spain, catalog no. CYT-QL-1), a fixative-free lysing reagent, which was allowed to act for 10 minutes, before sample acquisition.

To assure that $\mathrm{CD} 45^{-\mathrm{CD}} 146^{\text {+bright }} \mathrm{CD} 31^{\text {+bright }}$ events were $\mathrm{EC}$, additional staining was made with anti-CD146 (clone P1H12, BD Pharmingen), anti-CD31 (clone WM59, BDB), conjugated with PerCPCy5.5 and V450, respectively, and other mAbs known to be expressed by these cells: anti-CD309 (Vascular Endothelial Growth Factor Receptor 2, VEGFR-2) (clone 89106, R\&D systems), anti-CD105 (Endoglin) (clone 2H6F11, Immunostep) and anti-CD144 (Vascular Endothelial Cadherin, VE-cadherin) (clone 55-7H1, BD Pharmingen), conjugated with APC, PE and FITC, respectively. Since our intention was only to confirm the expression of these additional markers on the isolated EC, and only few leukocytes (CD45 ${ }^{+}$events) were present we didn't use anti-CD45 in this step, identifying the EC as being the events that were simultaneously CD $146^{\text {+bright }} \mathrm{CD} 31^{\text {+bright }}$.

\section{Flow cytometry acquisition and data analysis}

Samples were acquired within the first two hours of finishing the sample preparation, in a FACSCanto II flow cytometer (BDB), equipped with blue argon $(488 \mathrm{~nm})$, red $(633 \mathrm{~nm})$ and violet $(405 \mathrm{~nm})$ lasers, using the FACS Diva software (BDB). The instrument performance was monitored daily using the Cytometer Setup and tracking beads ${ }^{\mathrm{mi}}$ (BDB, San Jose, CA, USA, catalog no. 642412). Median number of 4.055 EC events were acquired per sample, ranging from 1.704 to 12.061 events. Data analysis was made with the Infinicyt ${ }^{\mathrm{TM}}$ software (Cytognos, Salamanca, Spain). Endothelial cells were defined as being CD45, CD146 ${ }^{\text {tbright }}$ and CD31 $1^{\text {+bright }}$. 


\section{Statistical analysis}

Data are expressed as median, minimum and maximum values of the mean fluorescence intensity (MFI) obtained for the expression of the different markers on the isolated EC and residual lymphocytes from 10 patients, calculated using the Microsoft Office Excel 2007. Comparative statistics was performed with the Mann-Whitney U nonparametric test, using SOFA Statistics, version 1.4.5 (Paton-Simpson and Associates Ltd, Auckland, New Zealand). P values $<0.05$ were considered to be associated with statistical significance.

\section{Results and Discussion}

Here we present an easy and cheap mechanical method to isolate $\mathrm{EC}$ from the vessel wall and we tested it by FCM, using a combination of three markers, two of them expressed by EC (CD146/MCAM and CD31/PECAM-1) and one that is not (CD45/LCA). With this combination of $\mathrm{mAbs}$ we guaranteed the identification of a welldefined EC population by their typical CD $45^{-} \mathrm{CD} 146^{\text {tbright }} \mathrm{CD} 31^{\text {+bright }}$ staining and we were able to exclude most of the cell populations that could be misinterpreted as $\mathrm{EC}$, such as $\mathrm{CD} 45^{\text {bright }} \mathrm{CD} 146^{+}$ lymphocyte subsets, perivascular cells, including pericytes, that are known to be $\mathrm{CD} 45^{-} \mathrm{CD} 146^{+} \mathrm{CD} 31^{-}$, and vascular smooth muscle cells, which are $\mathrm{CD} 45^{-} \mathrm{CD} 146^{+/ \text {low }} \mathrm{CD} 31^{-}$[34-39]. In a supplementary step, EC identification was reinforced with additional staining with anti-CD309 (VEGFR-2), anti-CD105 (Endoglin) and anti-CD144 (VE-cadherin).

Endothelial cells had a higher side scatter (SSC) and similar forward scatter (FSC) than the residual lymphocytes present in the sample, which means that they have equivalent size but are more complex cells (Table 1 and Figure 1a). As expected, EC did not express the pan-leukocyte molecule, CD45 (LCA), and they stained brightly and homogeneously for the CD146 (MCAM) and CD31 cell surface molecules (Table 1 and Figure 1a). The median percentage of EC found in the 10 samples analyzed was $9.6 \%$, ranging from $8.0 \%$ to $27.8 \%$ of total events, whereas leukocytes (CD45+ events) accounted for only a median percentage of $0.4 \%$, ranging from $0.1 \%$ to $3.4 \%$. Endothelial cell phenotype was quite similar in all samples studied, with low variation in FSC, SSC and the mean fluorescence intensity (MFI) of all the markers analyzed (Table1 and Figure 1a). In addition, the CD309 (VEGFR-2), CD105 (Endoglin) and CD144 (VE-cadherin) molecules were strongly expressed, assuring the correct identification of EC (Figure 1b).

One of the advantages of this method is to avoid the use of procedures and substances that can induce alterations on cell receptors expression, as have already been seen with the use of digestion enzymes, such as collagenase and proteinase $\mathrm{K}$, which are known to degrade connective tissues $[9,25,40,43,44]$. This method has the additional advantage of allowing, if desired, to explore, by FCM, the expression of activation-related, procoagulant and angiogenic molecules on freshly isolated EC, as well as to use EC for cell cultures, functional studies or drug testing.

Tisato et al., who isolated EC from HSVEC by combining enzymatic and mechanical methods with collagenase and blade scraping, used the same triad of mAbs to identify EC, among others; of note that in Tisato's study, EC expressed heterogeneously CD45 and had low intensity of CD31 expression, probably due to enzymatic induced artifacts [45].

In our analysis, the relatively low percentage of $\mathrm{EC}$ within the total events acquired, probably results from the fact these cells are displayed in monolayer, their isolation being accompanied by perivascular cells; in fact, it is well known that isolation by mechanical methods have inferior cellular yield than other methods [46]. Maybe this is the reason why of the previously published work there is few using mechanical isolation of $\mathrm{EC}$, when compared to the number of studies using enzymatic methods [8,9,11,47-50]. Nevertheless of the few work published using nonenzymatic methods to isolate and detach EC in cell culture, described no phenotype alteration or morphology change of EC over time, obtained numerous culture passaging, in comparison with enzymatic methods $[9,12,41,42]$. The degree of cell purity obtained by our method is enough for a proper characterization of the immunophenotype of the fresh isolated EC using multiparametric FCM; however, if a high purity is needed, these cells can be further purified using magnetic or FCM based sorting.

We are convicted that the procedure described herein can be useful to characterize the different phenotype spectrum that freshly isolated EC from large vessels can acquire in various pathological conditions, concerning the expression of activation-related, procoagulant,

\begin{tabular}{|c|c|c|c|c|c|c|}
\hline & & FSC-A & SSC-A & CD31 (V450) & CD45 (PerCP) & CD146 (PE) \\
\hline \multirow{2}{*}{ Negative controls } & MFI & $\begin{array}{c}31304 \\
(27640-39165)\end{array}$ & $\begin{array}{c}30969 \\
(23577-41964)\end{array}$ & $\begin{array}{c}3069 \\
(1433-5577)\end{array}$ & $\begin{array}{c}478 \\
(284-789)\end{array}$ & $\begin{array}{c}191 \\
(103-319)\end{array}$ \\
\hline & $\mathrm{CV}$ & $\begin{array}{c}65 \\
(61-74)\end{array}$ & $\begin{array}{c}110 \\
(90-125)\end{array}$ & $\begin{array}{c}358 \\
(272-641)\end{array}$ & $\begin{array}{c}551 \\
(332-684)\end{array}$ & $\begin{array}{c}353 \\
(254-606)\end{array}$ \\
\hline \multirow{2}{*}{ Lymphocytes } & MFI & $\begin{array}{c}52296 \\
(40618-62202)\end{array}$ & $\begin{array}{c}10618 \\
(9573-14052)\end{array}$ & $\begin{array}{c}595 \\
(449-888)\end{array}$ & $\begin{array}{c}19664 \\
(15583-24714)\end{array}$ & $\begin{array}{c}160 \\
(89-935)\end{array}$ \\
\hline & $\mathrm{CV}$ & $\begin{array}{c}36 \\
(28-39)\end{array}$ & $\begin{array}{c}21 \\
(18-25)\end{array}$ & $\begin{array}{c}129 \\
(82-299)\end{array}$ & $\begin{array}{c}27 \\
(22-36)\end{array}$ & $\begin{array}{c}319 \\
(123-586)\end{array}$ \\
\hline \multirow{2}{*}{ Endothelial cells } & MFI & $\begin{array}{c}42407 \\
(36974-54995)\end{array}$ & $\begin{array}{c}52692 \\
(38183-58665)\end{array}$ & $\begin{array}{c}64425 \\
(30714-87822)\end{array}$ & $\begin{array}{c}1726 \\
(1224-1996)\end{array}$ & $\begin{array}{c}13062 \\
(8154-22679)\end{array}$ \\
\hline & $\mathrm{CV}$ & $\begin{array}{c}44 \\
(35-50)\end{array}$ & $\begin{array}{c}40 \\
(36-47)\end{array}$ & $\begin{array}{c}51 \\
(41-64)\end{array}$ & $\begin{array}{c}63 \\
(55-89)\end{array}$ & $\begin{array}{c}85 \\
(65-90)\end{array}$ \\
\hline \multirow{2}{*}{$\begin{array}{l}P \text { (Endothelial cells } \\
\text { versus Lymphocytes) }\end{array}$} & MFI & 0.013 & $<0.001$ & $<0.001$ & $<0.001$ & $<0.001$ \\
\hline & $\mathrm{CV}$ & 0.001 & $<0.001$ & $<0.001$ & $<0.001$ & $<0.001$ \\
\hline
\end{tabular}

Abbreviations: MFI, mean fluorescence intensity; CV, coefficient of variation of the mean fluorescence intensity; FSC-A, forward scatter-area; SSC-A, side scatter-area; $\checkmark 450$, violet 450; PerCP, peridinin-chlorophyll protein; PE, phycoerythrin.

Scales: FSC-A, linear scale; SSC-A, exponential low scale; CD45 (PerPC), CD31 (V450), and CD146 (PE), logical scale

Results are presented as median (minimum - maximum) values of the MFI and CV, expressed as arbitrary units of fluorescence intensity.

$P$ values $<0.05$ were considered to be associated with statistical significance (Mann-Whitney $U$ test)

Table 1: Forward and side scatter values and median fluorescence intensity of CD45, CD31 and CD146 expression on endothelial cells extracted mechanically from the saphenous veins of 10 patients submitted to surgery for varicose veins, as compared with that observed on residual lymphocytes present in the samples. 
Citation: Torres C, Machado R, Lima M (2016) Mechanical Isolation of Human Endothelial Cells from Large Vessels for Flow Cytometry Immunophenotyping. J Tissue Sci Eng 7: 163. doi:10.4172/2157-7552.1000163

a

HSVEC1
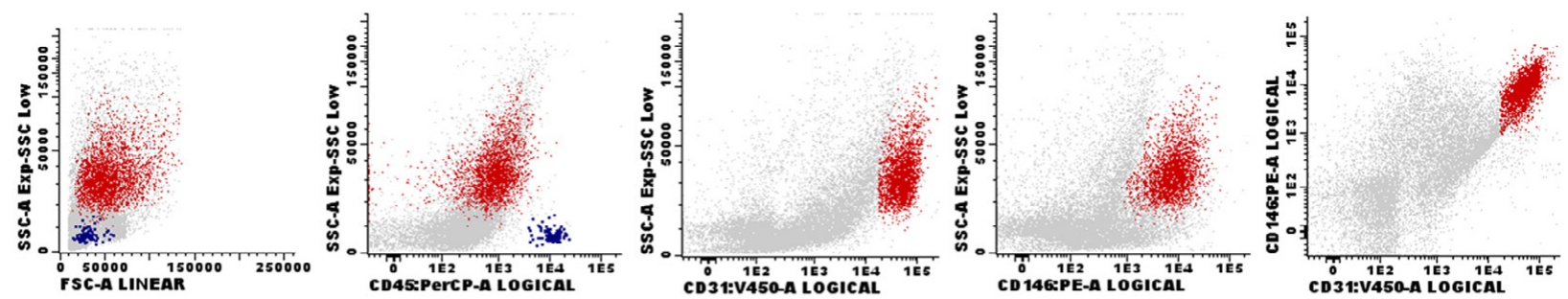

HSVEC2
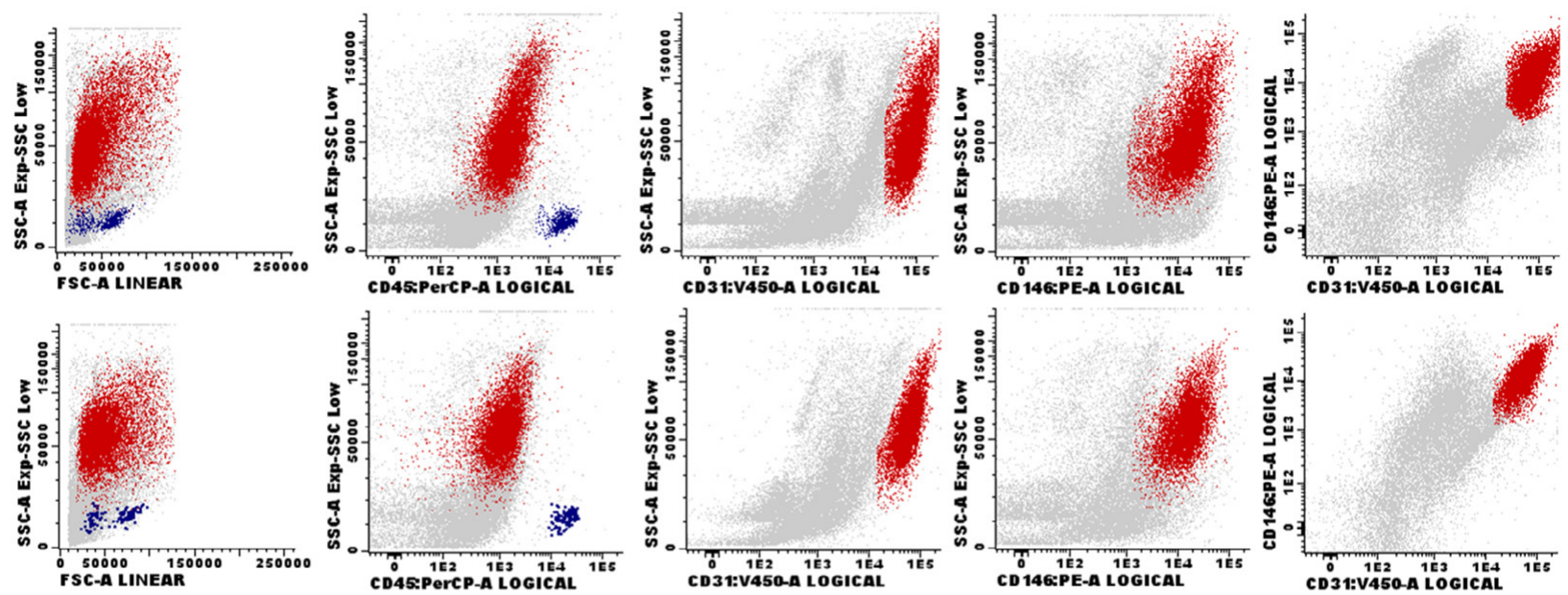

b
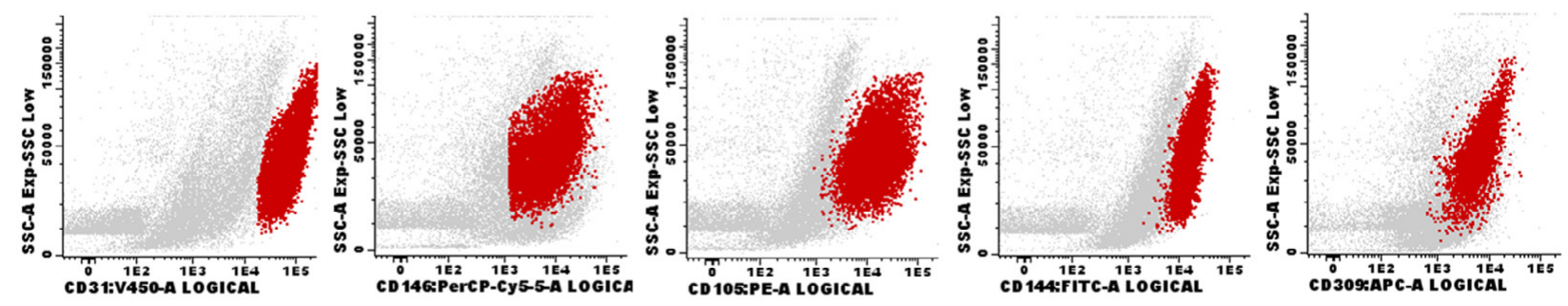

HSVEC4
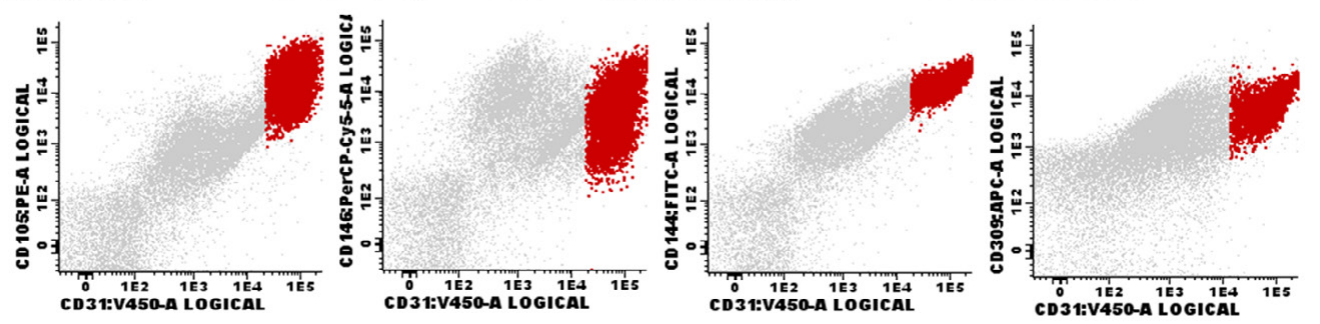

Figure 1: Representative dot plots illustrating the expression of cell surface receptors on endothelial cells (EC).

(a): Expression of CD45, CD146 and CD31 on EC (red dots), lymphocytes (blue dots) and other cells and debris (gray dots) in cell samples obtained from the saphenous veins of three different patients submitted to surgery for varicose veins (HSVEC1, HSVEC2 and HSVEC3). Note that EC are CD45 negative and do express brightly the CD146 and CD31 surface receptors.

(b): Expression of CD105 (Endoglin), CD144 (VE-Cadherin) and CD309 (VEGFR-2) surface receptors on EC obtained from the saphenous veins of a patient submitted to surgery for varicose veins (HSVEC4). Endothelial cells (red dots) were identified by expression of CD146+bright CD31+bright, and they show bright and homogeneous CD105, CD144 and CD309 expression.

apoptotic and/or angiogenic and anti-angiogenic molecules, avoiding the artifacts induced by enzymatic methods and/or cell culture. In the long term, it may contribute not only for a better characterization of the EC by FCM, but also to use them in other studies, in order to better understand their connection with the environment around and their contribution to various physiological and pathological states, as well as to develop new medications.

\section{Acknowledgments}

The authors thank all people who indirectly contributed to this work, namely the medical doctors, nurses and technicians from the Laboratory of Cytometry and Angiology and Vascular Surgery Service. They also thank to Enzifarma, for being sponsor of CD31 antibody used in this study, to the Multidisciplinary Unit for Biomedical Sciences of the Institute for Biomedical Sciences Abel Salazar, University of Porto (UMIB/ICBAS/UP), and to the Sociedade Portuguesa de Angiologia e Cirurgia Vascular (SPACV) for financial support. 
Citation: Torres C, Machado R, Lima M (2016) Mechanical Isolation of Human Endothelial Cells from Large Vessels for Flow Cytometry Immunophenotyping. J Tissue Sci Eng 7: 163. doi:10.4172/2157-7552.1000163

Page 5 of 6

\section{References}

1. Wu KK, Thiagarajan $P$ (1996) Role of endothelium in thrombosis and hemostasis. Annu Rev Med 47: 315-331.

2. Cines DB, Pollak ES, Buck CA, Loscalzo J, Zimmerman GA, et al. (1998) Endothelial cells in physiology and in the pathophysiology of vascular disorders. Blood 91: 3527-3561.

3. Danese S, Dejana E, Fiocchi C (2007). Immune regulation by microvascular endothelial cells: directing innate and adaptive immunity, coagulation, and inflammation. J Immunol 178: 6017-6022.

4. Young MR (2012) Endothelial cells in the eyes of an immunologist. Cancer Immunol Immunother 61: 1609-1616.

5. Aird WC (2012) Endothelial cell heterogeneity. Cold Spring Harb Perspect Med 2: 0006429

6. Jaffe EA, Nachman RL, Becker CG, Minick CR (1973) Culture of Human Endothelial Cells Derived from Umbilical Veins - Identification by Morphologic and Immunological Criteria. J Clin Invest 52: 2745-2756.

7. Booyse FM, Sedlak BJ, Rafelson ME (1975) Culture of arterial endothelial cells: characterization and growth of bovine aortic cells. Thromb Diath Haemorrh 34 825-839.

8. Ford JW, Burkel WE, Kahn RH (1981) Isolation of adult canine venous endothelium for tissue culture. In Vitro 17: 44-50.

9. Ryan US (1984) Isolation and culture of pulmonary endothelial cells. Environ Health Perspect 56: 103-114.

10. Cirillo P, Golino P, Ragni M, Guarino A, Calabro P, et al (1999) A simple method for the isolation, cultivation and characterization of endothelial cells from rabbit coronary circulation. Thromb Res 96:329-333.

11. Grenier G, Remy-Zolghadri M, Guignard R, Bergeron F, Labbe R, et al. (2003) Isolation and culture of the three vascular cell types from a small vein biopsy sample. In Vitro Cell Dev Biol Anim 39: 131-139.

12. Burciaga-Nava JA, Reyes-Romero MA, Avelar-Gonzalez FJ, Guerrero-Barrera AL (2009) Establishment and characterization of porcine aortic endothelial cell cultures with prolonged replicative lifespan by a non-enzymatic method. In Vitro Cell Dev Biol Anim 45: 15-18

13. Fehrenbach ML, Cao G, Williams JT, Finklestein JM, Delisser HM (2009) Isolation of murine lung endothelial cells. Am J Physiol Lung Cell Mol Physio 296: L1096-1103.

14. Van Damme N, Baeten D, De Vos M, Demetter P, Elewaut D, et al. (2000) Chemical agents and enzymes used for the extraction of gut lymphocytes influence flow cytometric detection of $\mathrm{T}$ cell surface markers. J Immunol Methods 236: 27-35.

15. Saper CB (2005) An open letter to our readers on the use of antibodies. J Comp Neurol 493: 477-478.

16. Rhodes KJ, Trimmer JS (2006) Antibodies as valuable neuroscience research tools versus reagents of mass distraction. J Neurosci 26: 8017-8020.

17. Fritschy JM (2008) Is my antibody-staining specific? How to deal with pitfalls of immunohistochemistry. Eur J Neurosci 28: 2365-2370.

18. Lorincz A, Nusser $Z$ (2008) Specificity of immunoreactions: the importance of testing specificity in each method. J Neurosci 28: 9083-9086.

19. Edwards GA, Fogh J (1959) Micromorphologic changes in human amnion cells during trypsinization. Cancer Res 19: 608-611.

20. Hodges GM, Livingston DC, Franks LM (1973) The localization of trypsin in cultured mammalian cells. J Cell Sci 12: 887-902.

21. Waymouth C (1974) To disaggregate or not to disaggregate injury and cell disaggregation, transient or permanent? In Vitro 10: 97-111.

22. Mulder WM, Koenen $H$, Van de Muysenberg AJ, Bloemena E, Wagstaff J, et al. (1994) Reduced expression of distinct T-cell CD molecules by collagenase/ DNase treatment. Cancer Immunol Immunother, 38: 253-258.

23. Abuzakouk M, Feighery C, O'Farrelly C (1996) Collagenase and Dispase enzymes disrupt lymphocyte surface molecules. J Immunol Methods 194: 211 216.

24. Van Landuyt KB, Jones EA, McGonagle D, Luyten FP, Lories RJ (2010) Flow cytometric characterization of freshly isolated and culture expanded human synovial cell populations in patients with chronic arthritis. Arthritis Res Ther 12: R15.

25. Grange C, Letourneau J, Forget MA, Godin-Ethier J, Martin J, et al (2011) Phenotypic characterization and functional analysis of human tumor immune infiltration after mechanical and enzymatic disaggregation. J Immunol Methods 372: 119-126.

26. Picot J, Guerin CL, Kim CLV, Boulanger CM (2012) Flow cytometry: retrospective, fundamentals and recent instrumentation. Cytotechnology 64 109-130.

27. Torres C, Fonseca AM, Leander M, Matos R, Morais S, et al (2013) Circulating endothelial cells in patients with venous thromboembolism and myeloproliferative neoplasms. PLoS One 8: 0081574.

28. Watt SM, Gschmeissner SE, Bates PA (1995) PECAM-1: its expression and function as a cell adhesion molecule on hemopoietic and endothelial cells. Leuk Lymphoma 17: 229-244.

29. Woodfin A, Voisin MB, Nourshargh S (2007) PECAM-1: a multi-functiona molecule in inflammation and vascular biology. Arterioscler Thromb Vasc Biol 27: $2514-2523$

30. Li Q, Yu Y, Bischoff J, Mulliken JB, Olsen BR (2003) Differential expression of CD146 in tissues and endothelial cells derived from infantile haemangioma and normal human skin. J Pathol 201: 296-302.

31. Elshal MF, Khan SS, Takahashi Y, Solomon MA, McCoy JP Jr (2005) CD146 (Mel-CAM), an adhesion marker of endothelial cells, is a novel marker of lymphocyte subset activation in normal peripheral blood. Blood 106: 29232924.

32. Elshal MF, Khan SS, Raghavachari N, Takahashi Y, Barb J, et al (2007) A unique population of effector memory lymphocytes identified by CD146 having a distinct immunophenotypic and genomic profile. BMC Immunol 8: 29.

33. Wang Z, Yan X (2013) CD146, a multi-functional molecule beyond adhesion Cancer Lett 330: 150-162.

34. Bardin N, George F, Mutin M, Brisson C, Horschowski N, et al (1996) S-Endo 1 a pan-endothelial monoclonal antibody recognizing a novel human endothelial antigen. Tissue Antigens 48: 531-539.

35. Shi S, Gronthos S (2003) Perivascular niche of postnatal mesenchymal stem cells in human bone marrow and dental pulp. J Bone Miner Res 18: 696-704.

36. Crisan M, Yap S, Casteilla L, Chen CW, Corselli M, et al. (2008) A perivascular origin for mesenchymal stem cells in multiple human organs. Cell Stem Cell 3: 301-313.

37. Covas DT, Panepucci RA, Fontes AM, Silva WA JR, Orellana MD, et al. (2008). Multipotent mesenchymal stromal cells obtained from diverse human tissues share functional properties and gene-expression profile with CD146+ perivascular cells and fibroblasts. Exp Hematol 36: 642-654.

38. Katare RG, Madeddu P (2013) Pericytes from human veins for treatment of myocardial ischemia. Trends Cardiovasc Med 23: 66-70.

39. Wang Q, Shen L, Huang W, Song Y, Xiao L, et al. (2013) Vasculogenesis of decidua side population cells of first-trimester pregnancy. Stem Cell Res Ther 4: 50 .

40. Ryan US, Mortara M, Whitaker C (1980) Methods for microcarrier culture of bovine pulmonary artery endothelial cells avoiding the use of enzymes. Tissue Cell 12: 619-635.

41. Scoumanne A, Kalamati T, Moss J, Powell JT, Gosling M, et al. (2002) Generation and characterisation of human saphenous vein endothelial cell lines. Atherosclerosis 160: 59-67.

42. Tan PH, Chan C, Xue SA, Dong R, Ananthesayanan B, et al. (2004) Phenotypic and functional differences between human saphenous vein (HSVEC) and umbilical vein (HUVEC) endothelial cells. Atherosclerosis 173: 171-183.

43. Perussia B, Trinchieri G, Cerottini JC (1979) Functional studies of Fc receptorbearing human lymphocytes: effect of treatment with proteolytic enzymes. J Immunol 123: 681-687.

44. Marks RM, Czerniecki M, Penny R (1985) Human dermal microvascular endothelial cells: an improved method for tissue culture and a description of some singular properties in culture. In Vitro Cell Dev Biol 21: 627-635.

45. Tisato V, Zauli G, Voltan R, Gianesini S, Di lasio MG, et al. (2012 Endothelia 
Citation: Torres C, Machado R, Lima M (2016) Mechanical Isolation of Human Endothelial Cells from Large Vessels for Flow Cytometry Immunophenotyping. J Tissue Sci Eng 7: 163. doi:10.4172/2157-7552.1000163

Page 6 of 6

cells obtained from patients affected by chronic venous disease exhibit a proinflammatory phenotype. PLoS One 7: e39543

46. Bachetti T, Morbidelli L (2000) Endothelial cells in culture: a model for studying vascular functions. Pharmacol Res 42: 9-19.

47. Gospodarowicz D, Moran J, Braun D, Birdwell C (1976) Clonal growth of bovine vascular endothelial cells: fibroblast growth factor as a survival agent. Proc Natl Acad Sci U S A 73: 4120-4124.

48. Björntorp P, Hansson GK, Jonasson L, Pettersson P, Sypniewska G (1983)
Isolation and characterization of endothelial cells from the epididymal fat pad of the rat. J Lipid Res 24: 105-112.

49. Kraan J, Strijbos MH, Sieuwerts AM, Foekens JA, den Bakker MA, et al. (2012) A new approach for rapid and reliable enumeration of circulating endothelia cells in patients. J Thromb Haemost 10: 931-939.

50. Post IC, Weenink RP, van Wijk AC, Heger M, Böing AN, et al. (2013) Characterization and quantification of porcine circulating endothelial cells. Xenotransplantation 20: 18-26. 